\title{
いかりさう(淫羊䳡) ノ藥理學的作用
}

\author{
第 2 報 \\ 滑本筋藏器二對スル作用及ビ家鬼尿量二及ボス \\ 影響亚二連續投與ノ生殖器二對スル影響
}

醫學士三宅 䱋 治

(岡山醫科大學藥理學敎室 [主任 奥㟫教授])

（昭和十二年六月十六日受付）

\section{緒言}

余 $^{1}$ ) 八景二古來支那, 朝鮮及ビ滿洲等二於テ所謂補精强壯: ノ目的二盛二煎川七ラル、 淫羊蕧, 即チいかりさう(Epimedium macranthum) ナル漢慗二關スル研究キ企テ, 先ヅ涂羊

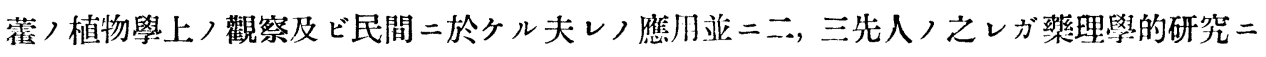
關スル業績キ述べ, 次デ余ノ研究二應用セルほざきのかりさう(Epimedium sagittatum) ヨリ抽出七ルえきすノ一般作月, 致死量, 血壓, 血管, 心臟亚二呼吸二及ボス影響二就テ詳 細二報告七り，即チ本えさすノ中等量ノ投與ハ青蛙 ラシメ, Maus 二於テハ著シク其隨意運動タ抑制スルモ，其大量キ投與シタル場合二限り間

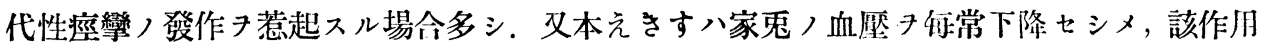
八增量スルニ從七顯著トナル。本えきす八家鬼耳㲄血管ニ對シテハ少量ニ於テノミ稀二收 縮的二作用スルノ外ハ少量ヨリ大量二至ル迄頗ル著明二えレタ擴張シ, 青蛙後肢血管二對 シテハ其作用法ハ家兔耳殸血管二於ケルト相似タルモ其感受性ハ前者二比シテ弱シ。而シ テ其血管作用ノ侵襲默占八血管筋自己二存シ植物性神經系二八關係ナキモノ、如シ. 又余八

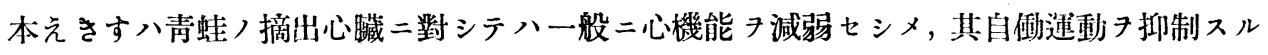
モ其作用ハ血管二對スルョリモ遙二弱キコトタ認メ, 更二其心臟作川ノ侵襲默心心筋自己 二存シ, 植物神經系統ハ之レ二關與セザルモノナルコトモ確メ得タリ. 又家兔ノ呼吸二對 シテハ本えきすハ影響極メテ尠ク，其大量习投興シタル場合卜踓モ極ク輕度ノ呼吸數つ檑 加及ビ呼吸媣度ノ堆大子惹起スルニ過ギズ.

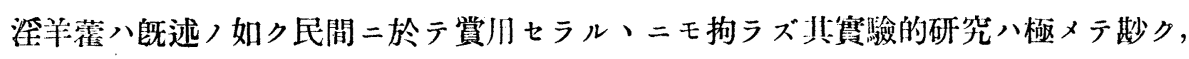

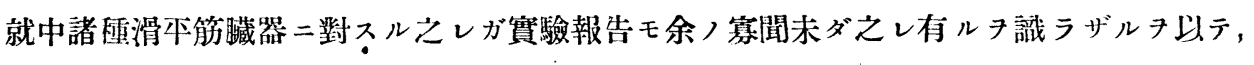
茲二余八家鬼ノ摘出腸管, 子宮, 蹄胱及ビ殬丸二對スル本えきす, 作川キ精細二研究シ, 唒 


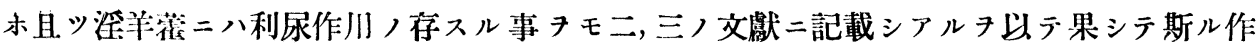

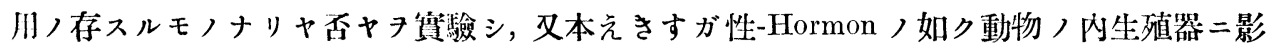

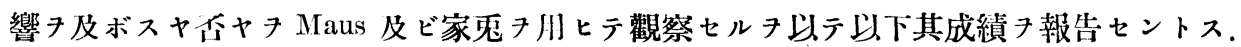

\section{I. 實驗材料及ビ賔驗方法}

摘出臟器二於ヶル實騟二八專ラ成熟家鬼 放血致死セシメテ直チ二摘出セル小腸管, 成熟不妊子宮, .膀胱及ビ睪丸二就テ, 總テMagnus >法=準據シテ實驗ヨ施行セルモノナルガ, 膀挄二於テハBähming-

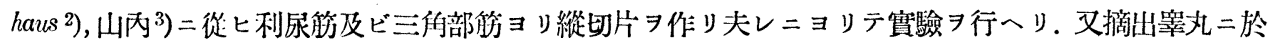

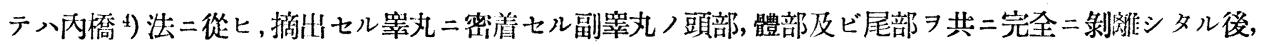
小ナルモノニ於テハ火レノ全體ヨ, 又大ナルモノニアリテハ之レ 2 片ノ條片トシテ用二供シタリ。次 二尿排泄二對スル實驗ニアリテハ總テ雄性家鬼 7 用七, 實驗前約 12 洔間絕食七シメタルモノ

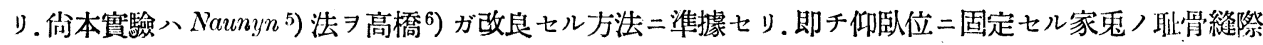
直上二於テ正中線二沿七約 $2 \mathrm{~cm}$ ，切開 7 行七, 膀挄 $\exists$ 腹腔外二引出シテ上方二翻轉シ, 次二可及的出血

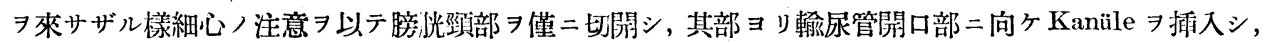

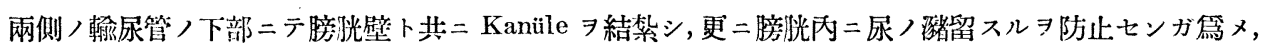
輸泉管閒口部ノ上方二テ尿ノ流出 リ滴下スル尿量 7 每 15 分二测定シ, 約 $2-3$ 洔間 7 經テ尿量略々一定スル 7 俟チテ藥夜 $\ni$ 耳靜胍內二極 メテ徐々二注射シ, 其後二排泄サル、尿量习計測セリ. 次二生殖器二對スル實驗ニ八幼若 Maus 及ビ幼

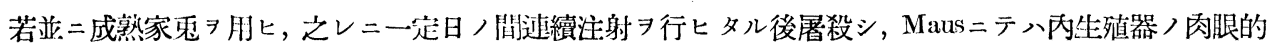
觀察 ，家鬼二テ入肉腿的觀察及ビ組織學的觀察

用二供セル滛学藿之きす八岡山祭科大學附屬醫院藥局二於テ製造セルモノニシテ, 用二臨ミ溫湯 以テ溶解シ適度二稀釋シテ用ヒタリ. 其えきすノ製法八第 1 報二詳細二記載シアル 以以テ此處二ハ之レ ᄏ省略又。

\section{II. 實 驗 成 綪}

\section{A. 滑平筋臟器ニ對スル作用}

\section{1. 摘出家鬼腸管二對スル作用}

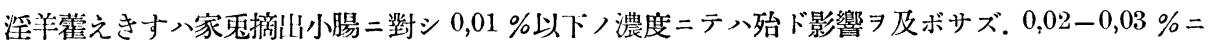
テ八藥液注加後僅二抑制作用發现シ,腸管ノ向働運動八減弱スルモ,一般二斯カル濃度二テハ其作用一過 性ニシテ, 間モナク蠅動運動入正常ニ復スルョ常トス. 然レドモ $0,05 \%$ 以上ノ濃度ニテハ腸管ノ運動八 著明二抑制サレ，其振幅入著シク縮小シ日、其緊張モ輕度二下降スル 7 觀ル。 $0,1-0,2 \%$ ノ本えきす

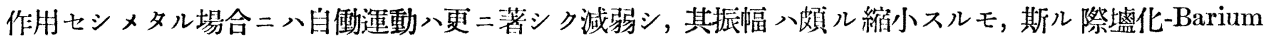

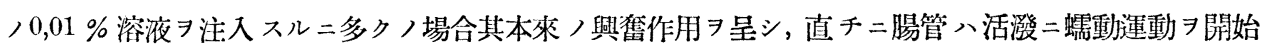
ス. 又同量/淫羊嚄えきすヨ作用セシメテ著シク自働運動/減弱七ル際, 副交感神經ノ末端习刺战シテ

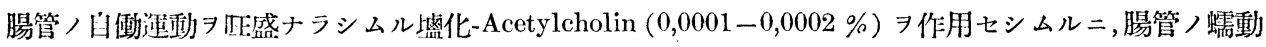
運動ノ克淮スルヨ觀ル. 然レドモ更二濃度习增シ $0,5 \%$ ノ本えきすヨ作用セシムル時八其抑制作用八頗 
ル㙷著ニシテ數分ヨ出デズシテ腸管入殆ド全ク靜止セントスルニ至ル. 斯ル際城化-Acetylcholin 7 注 加スルニ一過性, 腸管收縮、觀ラルルコトアルモ再ビ直チ二腸管, 運動入靜止セントス. 而シテ數分後

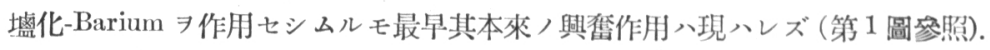

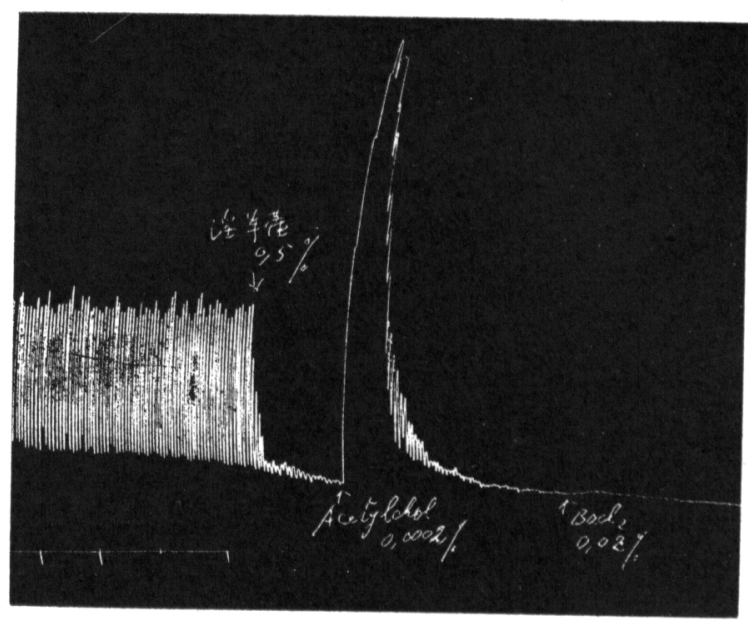

第 1 圖. 摘出家鬼腸管曲線.

淫羊堡光きす $0,5 \%$, 热化-Acetylcholin $0,0002 \%$, 㸃孟化-Barium $0,02 \%$ 適用. 時標得 1 分.

以上, 䁈羷成績二㨟レバ, 本えさすハ少量ヨリ大量二至ル过摘出家鬼腸管二對シ, 抑制 的二作用シ, 殊二其大量ニテハえレタ麻序七シム。而シテ斯ル抑制作用八本えさすガ副交 感神經,末端子麻淿スルニ因ルモノ二非ズシテ腸管筋自己尹侵謷スルニ因ルモノナラント 思惟サル，又本えさすノ腸管運動抑制作用ガ菼感神經卜關係尹有スルモノナリヤ否ヤ八遽 二えレタ眑定スル事能ハザルモ他,贜器二於テモ交感神經作用八全ク觀ラレザル事頯ヨリ

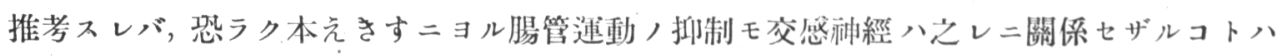
想像二難カラザル處ナリ。

\section{2. 摘出家鬼子宮二對スル作用}

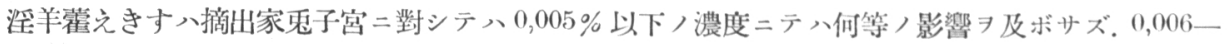
$0,01 \%$ >溶液习適用スレバ子宮ノ自働渾動入輕度二旺盛トナリ, 且ツ其緊張モ輕度二上昇ス. 而シテ斯

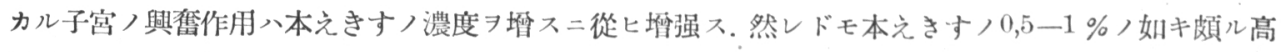

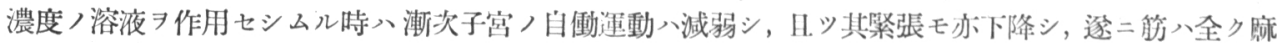

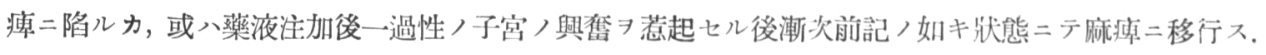
而シテ斯ル際子宮筋 7 刺钱與奮セシムベキ塩化-Barium 7 注加スルモ最早之レ二對シ何等影響 サズ.

斯クノ如ク，淫羊藮えきす八摘出家鬼子宮二對シテハ腸管二對スルトハ恢ル趣キタ異 


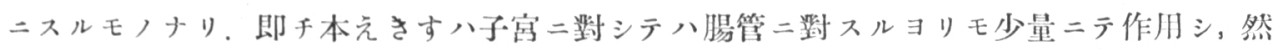
モ腸管二於テ、毫モ興虎作月八發現七ザルニモ拘ハラズ, 少量ヨリ可ナリ大量二至ル迄著

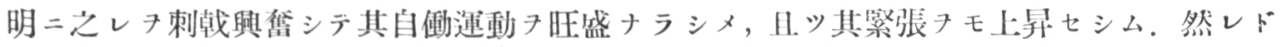

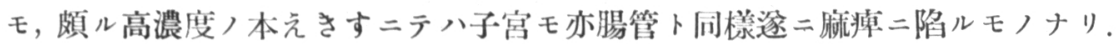

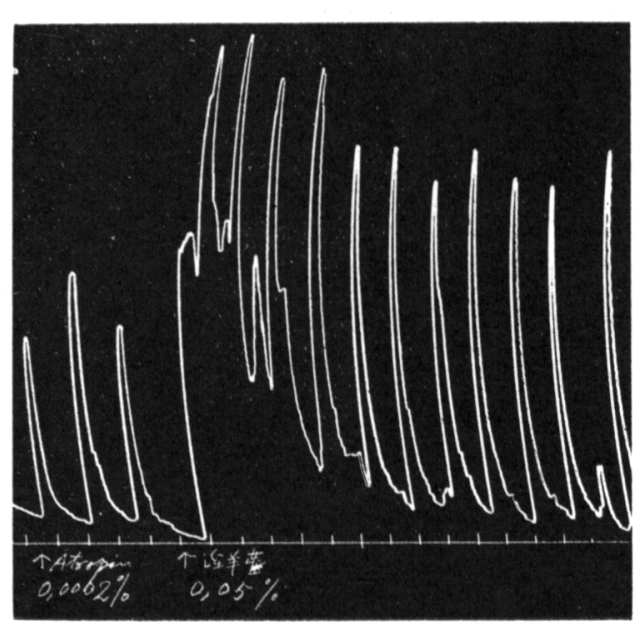

第 2 圖 A. 摘出家鬼子宮曲線。 硫 酸-Atropin $0,0002 \%$, 滛羊蕉えきす $0,05 \%$ 適用。 時標每 1 分.

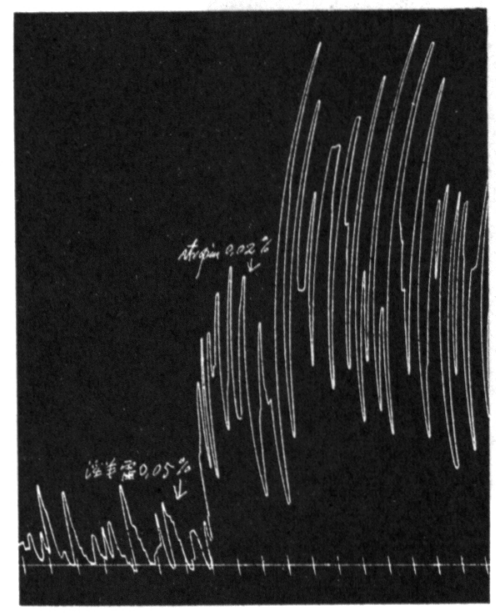

第 2 圖 B. 摘出家鬼子宮曲線。 滛羊萑えきす $0,05 \%$, 硫酸-Atropin $0,02 \%$ 適用 時標每 1 分.
次二本えきす,子宮興舊作用ガ如何ナル機

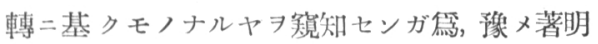
作用量タル $0,05 \%$ >本光きす 自働運動䭪盛トナリ且ツ其緊張〉上昇习惹起七 ル際, 副交感神經ノ末端 7 麻疾セシムル硫酸Atropin 八少量 $(0,0001-0,0002 \%)$ ヨ作用七シ ムル テ何等影響习蒙ルコトナシ. 又之ト区對二豫メ 前記量, 硫酸-Atropin 7 適用シ, 副交感神經, 末端习麻痺シオキタル後本えきす,適當量ヨ注 加スル二子宮八依然著明ノ興舊狀態习呈入（第 2 圖 A 參照).

サレバ本えきす, 子宮興奋作用八副交感神 經ニ八關係ナキコト丙カナリ.

然ラバ該興鹰作用八交感神經, 關與スルモ ノニ非ザルヤ. 余八茲二之レヨ究明センガ鹪,

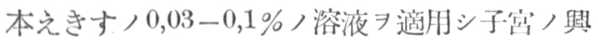
㸔 7 呈七ル際, 交感神經, 催進繊維 7 麻瘏七シ ムルテフ硫酸-Atropin ノ大量 $(0,01-0,02 \%)$ э 作用セシメタル二, 子宮, 垻舊、毫モ減弱スル コトナキカ, 或ハ却ッテ 硫酸-Atropin 自身/筋 刺战作用ノ加ハルコトニヨリテ一曆該興叐增 强サル、ヨ觀ル (第 2 圖 B 參照).

由是觀之，本えきすニョル子宮興奮作用八 交感神經ニモ亦䢦係ナキュト 7 識ル。

以上，實酠成績二㨡レバ，本えきす心 摘出家鬼子宮二對シテハ腸管二於ケルヨリ モ少量ヨリ作用シ, 且 ツ大量二至ル迄腸管 ニ覂テハ毫モ觀ラレザル興奮作月ノ每常發 現スルタ觀ル。而シテ其侵襲熱八子宮筋自 己二存シ，植物性神經系ハ何等之レ二關與

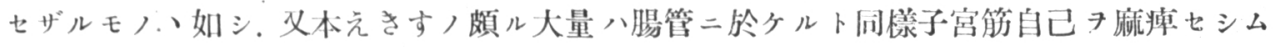


ルモノナルベシ.

\section{3. 摘出家鬼膀胱二對スル作用}

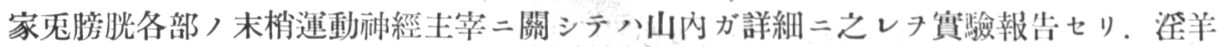
藿) 家鬼膀胱二對スル作用二關スル研究ハ未ダ之レヨ觀ザルキ以テ, 余ハ之レガ作用ヨ檢

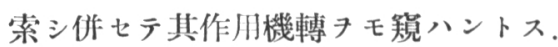

\section{a. 利尿筋二於ケル實驗}

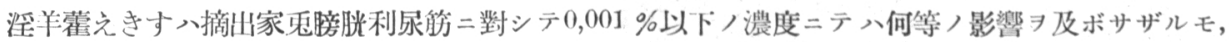
$0,001-0,002 \%$ ニテハ多クノ場合輕度二抑制作用現ハレ緊張ノ下降スルヨ觀ル. 而シテ斯カル抑制作用 八此較的長時間持續スル場合多シ.'本无きす>濃度 7 高メ $0,003-0,005 \%$ テ 八利尿筋二對スル抑制作

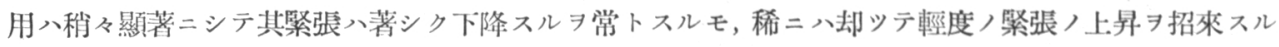
コトアリ. 更二本えきすノ濃度习高メ $0,01-0,02 \%$ 作用セシムル場合二八其抑制作用八盆々著明ニシ テ著シキ緊張，下降卜共二自働運動モ減弱ス。猫ホ $0,05-0,2 \%$ >如キ本えきす八高濃度溶液二テ八直 チ二其緊張八頗儿著明二下降シ且・其自働運動ハ著シク減弱スルカ, 或八全ク停止スル二至ル。斯カル

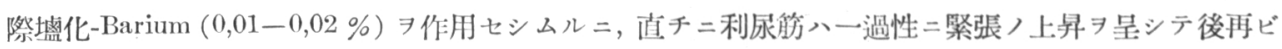

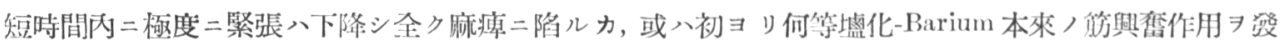
現七ズ (第 3 圖 A 參照).

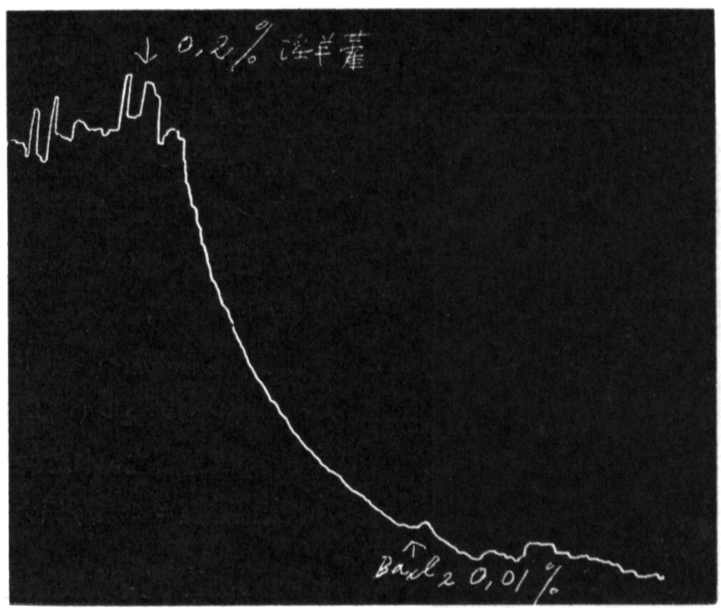

第 3 圖 A. 摘出家鬼膀胱利尿筋曲線.

滛羊䔨光きす $0,2 \%$, 壗化-Barium $0,01 \%$ 適用.

次二既述ノ如キ稀二發現スルコトアル本えきす>利尿管興整作用ガ如何ナル機車專二因ルモノナル

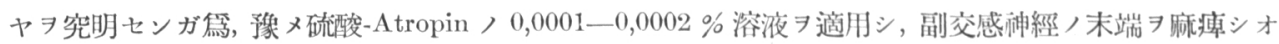

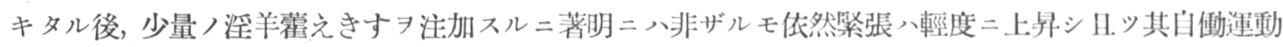

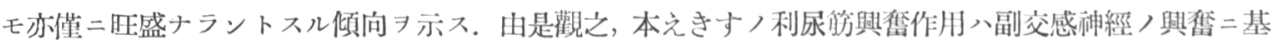




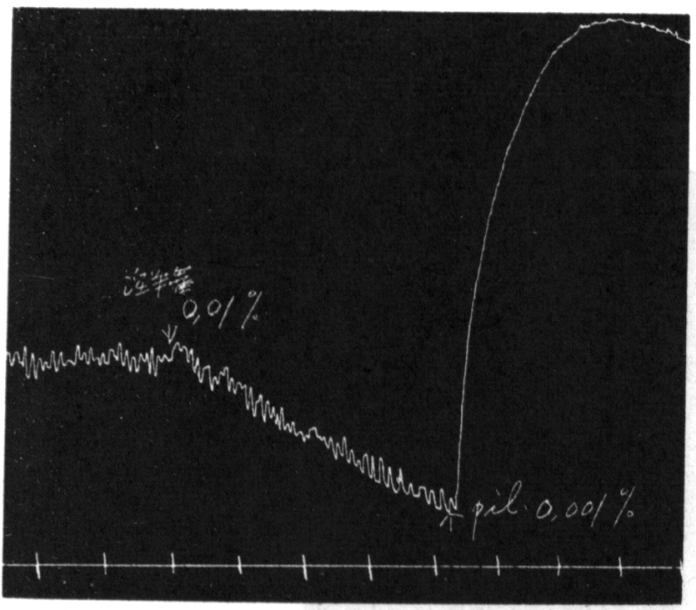

第3 圖 B. 摘出家鬼膀胱利尿筋曲線。

淫羊堂えきす $0,01 \%$, 監酸-Pilokarpin $0,001 \%$ 適用。 時標每 1 分.
クモノニ 八非ズシテ恐ラク子宮筋ニ於ケル 卜同樣利尿筋自己, 興舊二基クモノナラン 卜思惟不、又本えきすノ高濃度溶渡ニヨル 利尿筋, 抑制作用カ竻麻痺ニヨルモノナル コトハ既述セル 處ナルガ, 本えきすノ低濃 度溶液二ヨル抑制作用ガ副交感神經末端, 麻疩ニョルモノニ八非ザルャヨ炳カニセン ガ篇, 豫入淫羊藿えきすノ $0,01 \%$ 溶液 7 作 用セシメ、利尿筋, 緊張著シク下降スル際,

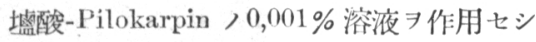
ムル二, 直チ二筋〉緊㲀、著明二上昇セリ (第 3 圖 B 參照).

即千本えきすノ少量ニヨル利尿管ノ抑 制作用モ副交感神經二八關係ナキモノト思 考サル。

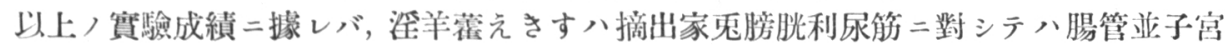
二對スルヨリモ少量ニテ克ク作用シ, 大量ニ至ル迄一般二之レタ抑制シ,特二其袩張子下降 七シムル作用顯著ナリ。而シテ稀二本えさす,少量二於テ利尿筋, 興奮子萑起スルコトア リ。等作用，侵謷點八腸管及ビ子宮二於ケルト间樣利尿筋自己二存シ，植物神經系八之 レニ關與セザルモ, 、如シ。文本えきす,大量八利尿筋自己尹麻疩七シムルモノナルベシ。

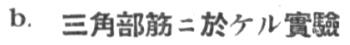

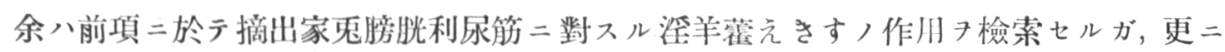
三角部筋二對シテモ之レガ顀驗タ行ヒ，次ノ如キ成績ヨ得タリ。

滛羊黨えきす八三角部筋二對シテ八利尿筋二對スルガ如ク作用强カラズシテ， $0,005 \%$ >本えきす

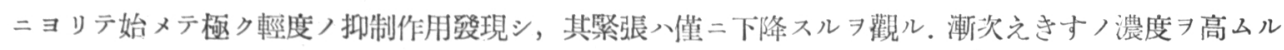

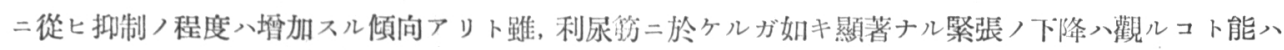
ザリキ. 唒ホ本えきすノ $0,1-0,2 \%$ >如キ高濃度液ニヨリテ著シク筋)緊張下降シ日.ッ其自働運動モ頗

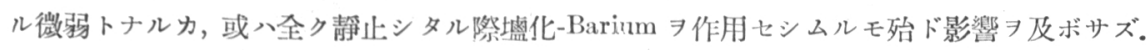

斯)如ク，本气さ方角部筋二對シテハ利尿筋二對スル程作用顯著ナラズ. 然モ利 尿筋二於テ稀二觀ラレタル筋, 興墕モ三角部筋ニ於テ八毫モ發現セズシテ，本えきす八總 テノ量二於テ每常抑制的二, ミ作用スルモノナルコトタ誐リタリ.

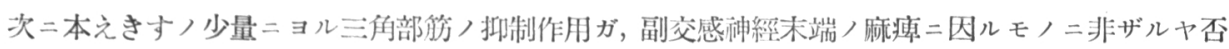

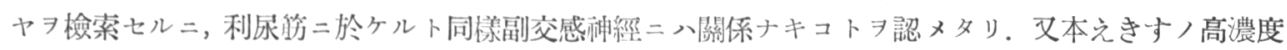

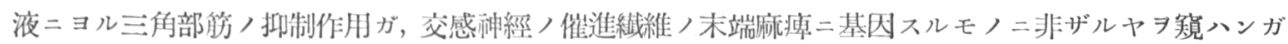

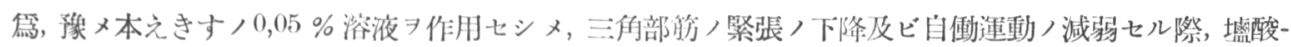


Adrenalin $>0,0001 \%$ > 溶液 $\exists$ 注加七ル二, 直チ二筇〉緊張八頗ル 著明二上昇シ, 盐酸-Adrenalin ノ大

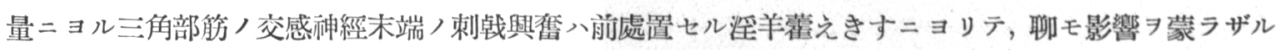
コトヨ闆明ナラシメタリ(第 4 圖 參照).

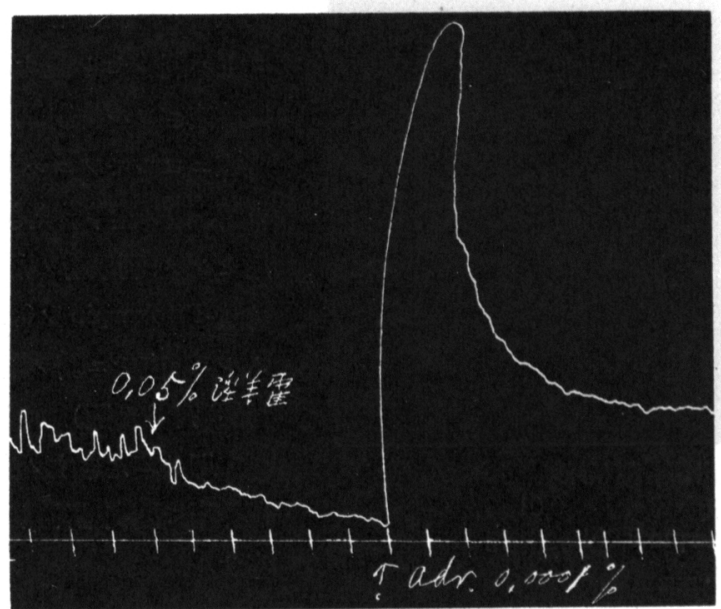

第 4 圖．摘出家鬼膀脱三角部筋曲線．

淫羊萑光きす $0,05 \%$, 垛酸-Adrenalin $0,0001 \%$ 適用。 時標每 1 分。

以上, 實驗成績二橡レバ, 本えさすハ三角部筋二對シテ八利尿筋二對スルヨリモ其作 用弱ク, 目ツ每常之レタ抑制スルモノナレドモ, 其作用八利尿筋二於ヶルガ如ク顯著ナラ ズ. 又其侵襲點八專う筋自己二存シ, 植物性神經系二八關係ナキモ, ト思惟ス, 又本壳きす ,大量が三角部筋自己ヌ麻㾝セシムルコトハ他, 臓器ニ於ケルト同情ナリ。

\section{4. 摘出家鬼辠丸二對スル作用}

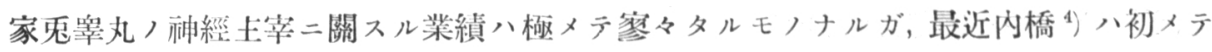
Magnus, 法ニヨリテ摘出七ル家鬼睪丸ノ運動神經ニ關スル精細ナル䊾理學的研究 フ行七,

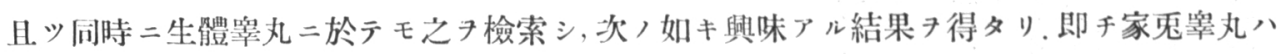
副殬丸卜八無關係二規則正シキ律動的自働運動 營々, 該自働運動八交感並二副交感神經 ニヨリテ主宰七ラレ, 摘出家鬼殬丸二於テ八交感神經性催進並二抑制兩繊維及ビ副交感神

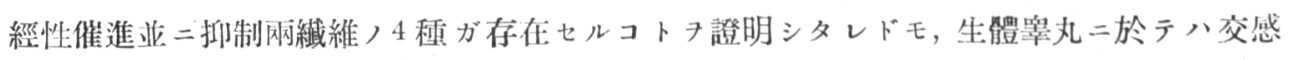

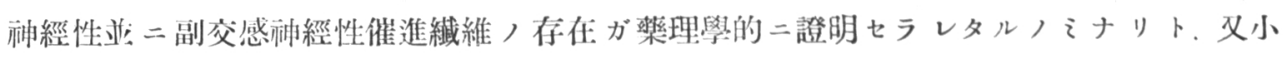

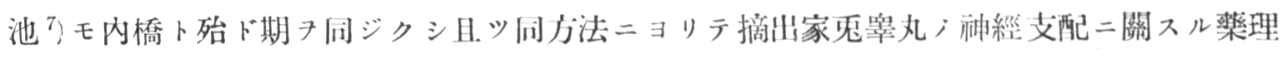
學的研究子行七, 家鬼殬丸滑本筋二八交感神經, 促進亚二抑制, 网繊維ノ分布スルモノナ レドモ, 副交感融經, 分布スルコト八確認スルコト能ハズト報告セリ. 即于网氏, 研究二 ヨレバ, 摘出家鬼睪丸二對スル交感神經, 所見ハ相一致スルモ副交感神經二關シテ八聊力 
見解キ㟟ニセリ。

强精作用アリトシテ古來愛用サル、滛羊䔄ガ家鬼睪丸自働運動二對シテ如何ナル影䠹 ヨ及ボスヤ, そレキ檢索スルモ亦頗ル興味アルモノト信ズルキ以テ余八詳細二之レガ研究 キ行ヒ, 以テ得タル結果キ获二報告セントス。

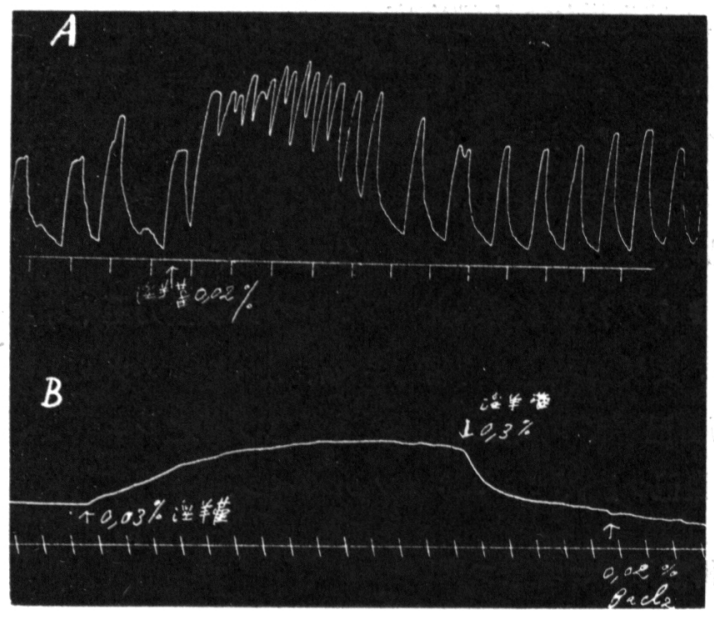

第 5 圖 A,B. 摘出家鬼睪丸曲線。

A：淫羊蕉えきす $0,02 \%$,

B：淫羊蒮えき十0,03\%,0,3\%， 盐化-Barium $0,02 \%$ 適用. 時標每 1 分.

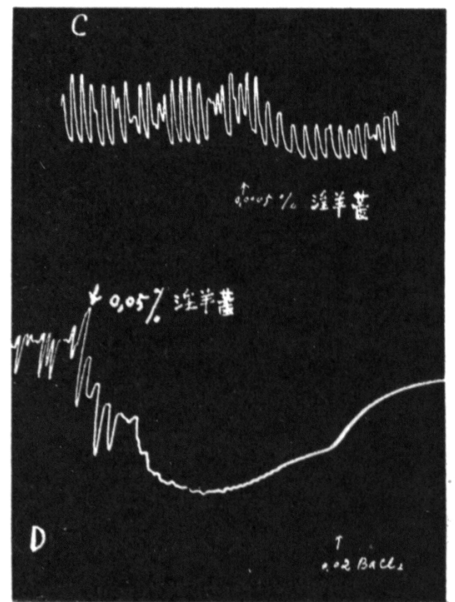

第 5 圖 C,D. 摘出家鬼首丸曲線、

$\mathrm{C}$ ：淫羊嚄えきす $0,0005 \%$,

D: 淫羊蕉えきす $0,05 \%$, 盕化-Barium 0,02\% 適用。
淫羊蕓えきすハ少量及ビ中等量二於 テ八摘出家鬼㙜丸滑平篊二對シ主トシテ 興奮的二作用ス. 即千本えきすノ0,001\% 以下二テハ其作用未ダ發現セザルモ，尠 シク其量ヨ增スコトニヨリ輕度二辠丸ノ 自働運動ハ旺盛トナリ, 且ッ其緊張乇上 昇不. $0,01-0,03 \%$ 二テ 夫等〉傾向、 㿽々强盛トナルョ常トシ,稀ニハ $0,1 \%$ ， 如キ本之きすノ高濃度液二テモ唒小著シ ク筋ノ緊張ヨ惹起スルコトアリ。然モ斯 カル筋,緊张, 上昇八可ナリ長時間持續 スル場合多シ。然シ乍ラ本えきすノ0,3\% 以上ノ濃度二テハ筋, 繁張八全ク下降シ 罝化-Barium $(0,01-0,02 \%) \quad \exists$ 作用七シ ムルモ最早之レ二對シ何等ノ影響 サザルニ至ル (第5 圖 A, B 參照).

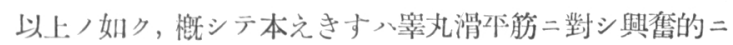
作用スルモ, 又之レト反對二寔々抑制的二作用スル場合モアリ. 即于斯カル場合二八 $0,0002-0,0005 \%$ /本えきす二テ睪丸ノ自 働運動ハ極ク輕度二抑制サレ月ツ其繁張正輕度二下降ス. 而シ テ斯カル 抑制作用八本えきすノ濃度习增ス二從ヒ强度トナル モ， $0,01-0,02 \%$ ，如キ濃度二於テモ猛木此較的短時間二テ・正 常二復スル場合多シ. 然レドモ斯クノ如ク寧口抑制作用ノ克ク 發現スル睪丸ニアリテハ既ニ本えきすノ $0,05-0,1 \%$ 二テ殆ド

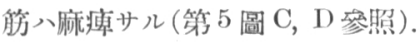

次二本えきす, 峷丸二對スル作用機轉 7 筧知センガタメ,

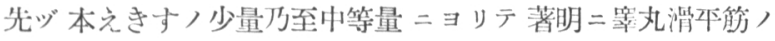
祭張,上昇七儿際, 硫酸-Atropin 八少量 $(0,0001-0,0002 \%) \Rightarrow$ 作用七シムル二何等, 影響 $尹$ 蒙ルコトナキ Atropin 八大量 $(0,01-0,02 \%)$ 作用セシムルニ, 茲二於テモ 亦何等ノ影響ナキコトヨ確認セリ。

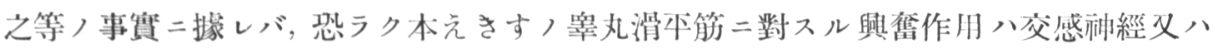
副交感神經ノ催進䋐維ノ剌战興奮ニヨルモノ二八非ズト思惟サル。然ラバ等丸二對スル本 


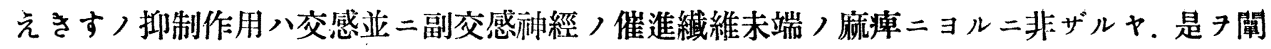
明ナラシメンガ篇, 可ナリ高濃度ノ本えきす尹作用セシメ著シク筋ノ緊張下降シ且ッ自働

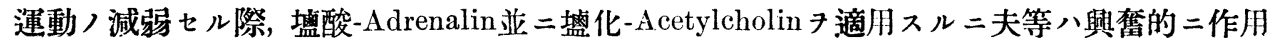
シ，直キ二筋ノ緊張ハ著シク上昇スルフ認ム，即千之等ノ事賽二據レバ，本えきすノ辠丸 二對スル抑制作用八交感並二副交感神經ノ催進緎維ノ末端麻㾝ニョルニ非ザル事柄ナリ. 然ラバ斯カル抑制作用八交感並二副交感神經ノ抑制織維ト關係タ有スルモノニ非ザルヤ,

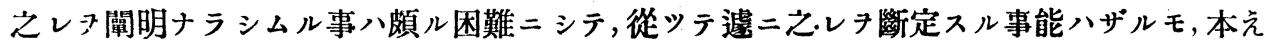

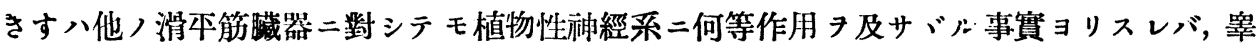
丸滑本筋二對スル抑制作用モ寧口筋自己二存スルモノト考フルガ穻當ナラン.

以上ノ賽驗成績二據レバ，滛羊藿えさすハ摘出家兔辠丸二對シテハ其少量乃至中等量 二於テハ多ク，場合興奮的二作用スルモ，又反對二屡々抑制的二モ作用スルモノナリ。而 シテ其侵襲點〉何レノ場合モ辠丸滑本筋自己二存シ，植物性神經系ハ恐ラクえレ二關興セ ザルモノ、如シ. 又本えきすノ大量ハ筋自己す麻煌セシムルモノナルべシ。

\section{B. 家鬼ノ排泄尿量二及ボス影響}

尿探取手術後尿量/略々一定スル $ヨ$ 待チテ淫羊鹤えきす 八尿量二變化ナシ. $20-30 \mathrm{mg}$ 二テハ注射後 15 分二シテ既二輕度二尿量入減少シ始メ，1時間後二八其 減少度最モ高ク，注射前ノ尿量二比シ約 $20-40 \%$ >減少

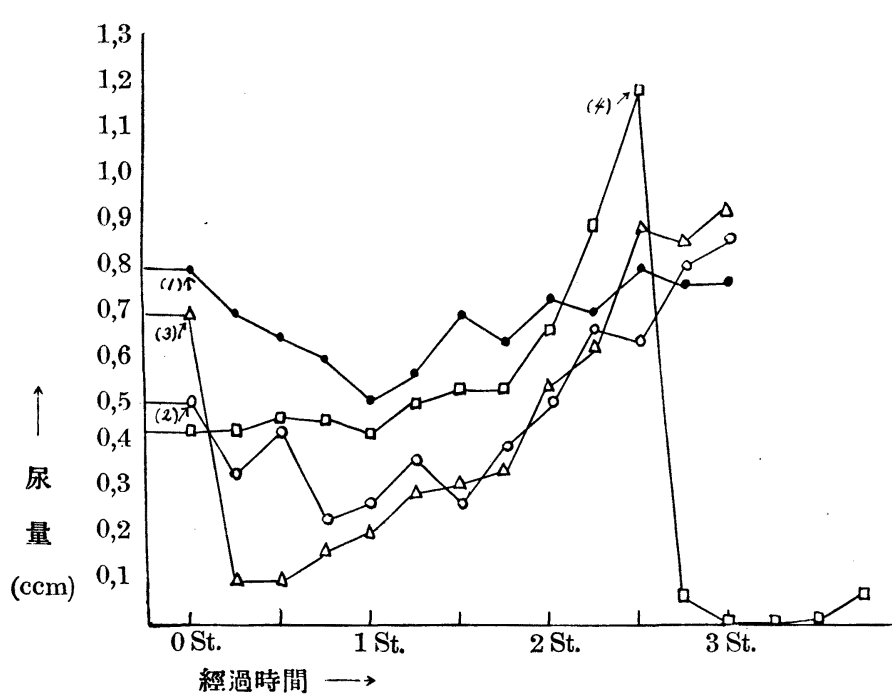

第 6 圖. 家鬼尿量二及ボス滛羊蒦えきす，影響．

（1）滛羊菁えきす $30 \mathrm{mg} / \mathrm{kg}$ 耳靜脈內注射

(2) $\quad 50 \mathrm{mg} / \mathrm{kg}$

(3) $\quad " 100 \mathrm{mg} / \mathrm{kg}$

(4) " $150 \mathrm{mg} / \mathrm{kg}$
間後二八殆ド舊量二復ス。 $50 \mathrm{mg}$ 习注射ス几時八盆々 尿量ノ減少度八增强シ，注 射後 $30-45$ 分目二八最高 二達スルョ認ム. 而シテ注 射後 2 洔間习經テ後却ッテ 尿量ノ著シク增加スル事 居々認ムルモ, 之レハ多數 /家鬼二於テ, 何等藥品 7 投與セザル場合二於テモ尿 量略々一定セル後約 2 時間 ヨ經過スレバ著シク尿量ノ 自然增加习惹起スル事頗儿 多キ事ヨリ考フレバ, 必シ モ淫羊鹤えきすノ作用 $=ヨ$ ルモノト八思惟サレズ. 次 二本之きす $100 \mathrm{mg}$ 习注射 ル二, 尿量八急擞二月ッ高 


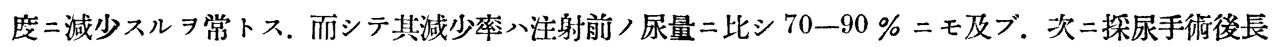
時間习經テ藥品ノ投與ナク自然二尿量ノ堆加 7 招來セル際, 本えきすノ $150 \mathrm{mg}$ ᄏ注射シタル $=15-30$ 分ニシテ尿量八極度二減少スルカ,或八全ク杜絕スルョ認メタリ(第 6 圖 參照).

余八又實驗中尿ノ蛋白反應 7 檢シタルニ常二陰性ナルコトヨ確メタリ.

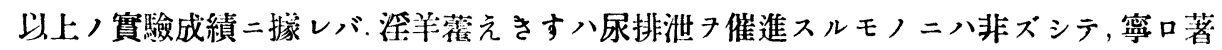
明ニ之レ・抑制シ，尿量フ減少セシムルモノナリ，

\section{C. 連續投與ノ生殖器ニ對スル影㗽}

古來强精作川アリトシテ民間二煊俌サル、いかりさう二果 シテ生殖器二對シテ, 性Hormon 等二觀ラル、ガ如キ作用ノ發現スルモノナリヤ否ヤタ探求スル事八蓋シ最モ興味 アル事ナラン. 余ハ淫羊萑えきすキ以テMaus及ビ家兔キ用ヒテえレタ實驗シタルタ以テ茲 ニ其結果タ報告セントス.

\section{Maus ニ於ケル赛験}

Maus 二於テハ其體重 $7-9 \mathrm{~g}$ /幼若ナルモノ 7 選ビ, 5 匹ヨ以テ 1 群トナシ, 各群 $0,2 \mathrm{mg} / \mathrm{g}$ 及ビ 0,7 $\mathrm{mg} / \mathrm{g} 7$ 每日一定時間 $=1$ 回宛 5 日間連續シテ其背部皮下二注射シ, 注射 7 完了七ル䍿日之レ 7 屠殺シ,

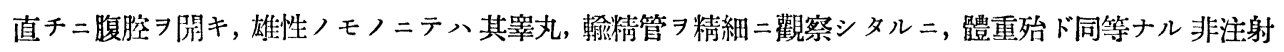
Maus 二於ヶル夫等ト何等差巽ヨ認メズ, 即チ夫等/部分ノ充血, 肥大等全ク觀ラレザリキ. 猶ホ又雌性 Maus 二於テモ同栐ノ方法 $ヨ$ 以テ檢索シタル二, 其子宮及ビ卵巢二於ヶル肉眼的所見八對照動物ノ夫等 ト何等差㟟ナキコトヨ識リタリ。

\section{2. 家鬼ニ於ケル贯櫭}

家鬼二於テ 八雌雄共二體重 $1,5 \mathrm{~kg}$ 以下/幼若ナルモノ, 及ビ $1,8 \mathrm{~kg}$ 以上ノ成熟セルモノ 7 實驗二供 シ, 之レニ各群 $50 \mathrm{mg} / \mathrm{kg}$ 及ビ $100 \mathrm{mg} / \mathrm{kg}$ ᄏ每日 1 回宛一定時間二耳靜胍內 =注射シ, 5 日間持續シタル

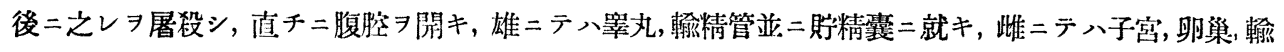

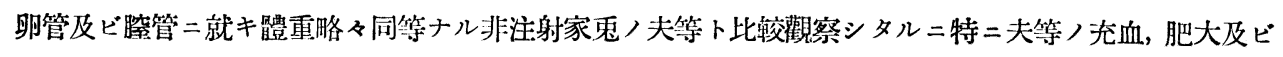
柔軟等ノ狀ハ觀ラレザリキ。

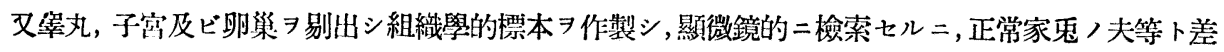
異习認メザリキ.

由是觀え, 滛羊藮えきすノ連續注射ハMaus 及ビ家鬼ノ生殖器二對シ肉眼的並二組織學

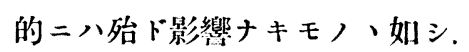

\section{III. 總 括}

1. 滛羊薮えきす八摘出家息腸管二對シテハ少量ヨリ大量二至ル迄專ラ抑制的二作用 シ, 殊二其大量ハえレタ麻㸣セシム。而シテ斯カル腸管運動ノ抑制作用、植物性神經系二 
八關係さクシテ，恐ラク本えきすガ腸管筋自己キ侵襲スル篇ナラン.

2. 本えさ摘出家鬼子宮二對シテ八腸管二對スルヨリモ少量二テ作用シ，然モ少 量ヨリ可ナリ大量二至ル迄, 腸管二於テハ毫モ觀ラレザル興奮作用ガ每常且ツ顯著二發現 ス. 然レドモ其侵襲默了腸管二於ヶル夫レト同樣筋自己二存シ，植物性神經系ハ之レ二關 與七ザルモ，如シ。而シテ斯クノ如ク著明ナル興奮作用キ及ボスニモ拘ハラズ，本えき すノ大量ハ子宮筋㯌二魔㾕七シム。

3. 本えさす摘出家鬼膀胱利尿筋二對シテ八腸管亚二子宮二對スルヨリモ更二少量 ニテ作用シ, 其ノ少量二於テ稀二輕度二興奪丹惹起スル外ハ一般二總テノ量二於テ之レタ 抑制シ，殊二其緊張尹弛緩セシムル作用顯著ナリ。而シテ其作用默门腸管及ビ子宮二於ヶ ルト同軌ナリ.

4. 本えさす摘出家兔膀胱三角部筋二對スル作用法亚二其作用點八利尿筋二於々ル ト相似タルモ，一般二利尿筋ノ場合二比シテ其作用弱シ.

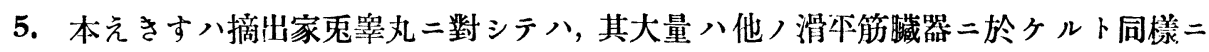
滑本筋尹麻煌スルモノナレドモ, 其少量乃至中等量ニテハまトシテ辠丸筋八興奮狀態トナ リ, 其緊張八著明二且兴比較的長時間上昇スルモノナレドモ，又夫レト反對二略々同量二テ 殬丸筋二對シ抑制的二作用スル場合モ屡々アリ。唒ホ其侵襲默占八他ノ贜器二於々ルト同樣 植物性神經系二ハ關倸ナク主トシテ幸丸筋自己二存スルモノナラン.

6. 本えきすフ家兔ノ耳靜脈內二注射スル二, 排泄サル、尿量八常二減少ス. 而シテ其 減少率八概泉本えきすノ量二比例シテ霄加ス.

7. 本えきす幼若雌雄 Maus ノ皮下二連續注射シタル後えレキ悋檢スルニ內生殖器 二於テ八肉眼的二八何等, 晎狀 認メズ. 又幼若亚二成熟踓雄家兔ノ静脈內連續注射二於

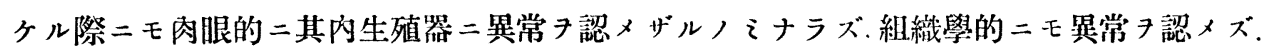

\section{引用書 目}

1) 三宅：岡山醫學會雜誌二發表ノ豫定.

2) Böhminghaus: Zeitschr. f. d. gesamt. exp. Med. 33, 378 (1923).

3) 山冈：岡山醫學會雜誌 432 號，1及ビ 436 號，574 (大正 15 年).

4) 内橋：同 誌 47,1940 (昭和 10 年).

5) Naunyn: A.rch. f. exp. Pathol. u. Pharmakol. 3, 102 (1875).

6) 高橋：岡山醫學會雜誌 424 號, 16 (大正 14 年).

7) 小池：篔驗藥物學雜誌 9,131 (昭和 10 年). 


\section{Dr. Michitada Funayama.}

Aus dem Pharmakologischen Institut der Kaiserlichen Universität Kyôto.

(Prof. Dr. Yoshizumi Ozaki.)

Eingegangen am 15. Juni 1937.

Verfassers Untersuchungen wurden nach der Deckglasmethode an Fibroblastenkulturen, die aus den Herzkammern von Hühnerembryo stammten, angestellt. Die aliphatischen Amine, die dabei geprüft wurden, waren die folgenden : Monomethylamin, Monoäthylamin, Dimethylamin, Diäthylamin, Trimethylamin, Triäthylamin, Monoäthylendiamin, Diäthylendiamin, Trimethylendiamin, Tetramethylendiamin und Pentamethylendiamin (alle als Hydrochloridsalz gebraucht). Die Hauptergebnisse sind zusammengefasst wie folgt: Auf das Kulturwachstum wirken die obengenannten Amine in schwachen Konzentrationen mehr oder weniger fördernd. Aber über eine gewisse Konzentration hinaus kommt es zur Hemmung. Die Wachstumshemmung wird mit vermehrter Dosierung der Amine immer ausgesprochener, bis schliesslich das Wachstum gänzlich aufhört. Bei der Wachstumsförderung ordnen sich die neugebildeten Zellen allmählich dichter aneinander an, die Fettkörnchen im Zytoplasma werden feiner und fast gleich gross, und im Zelleib sind keine Vakuolen zu bemerken. Im Gegensatz dazu nimmt bei der Wachstumshemmung die Zelldichtigkeit ab und weisen die Zellen unregelmässig polygonale oder rundliche Gestalt auf. Die Fettkörnchen in der Zellen werden grösser und zahlreicher, und es kommt überall zu Vakuolen. Die Kernkörperchen werden unregelmässig, und im extremen Falle bemerkt man Pyknose der Kerne und Protoplasmazerfall. Wenn man die Stärke der gewebeschädigenden und deshalb wachstumhemmenden Wirkung der obigen Amine hinsichlich ihrer gleichmolekularen Konzentration miteinander vergleicht, so findet man, dass die Monoamine schwächer als die Diamine wirken, und weiter sieht man, dass die Giftigkeit der Mono- bzw. Diamine, wenn auch nicht beträchtlich, etwa in folgender Reihenfolge zunimmt: Monomethylamin und Monoäthylamin, Dimethylamin und Diäthylamin, Trimethylamin und Triäthylamin, Monoäthylendiamin und Diäthylendiamin, Trimethylendiamin, Tetramethylendiamin, Pentamethylendiamin. [Vyl. Original (Japanisch) S. 33.] (Autoreferat.)

\section{Pharmakologische Studien über die Wirkung des Extraktes von Epimedium macranthum (旄羊鹤). II. Mitteilung. Einfluss auf die glattmuskelige 0rgane, Harn- absonderung und Geschlechtsorgane.}




\section{1)r. Shinji Miyake.}

Aus dem Pharmakologischen Institut der Medizinischen Fakultät Okayama.

(Vorstand: Prof. Dr. Kwanichirô Okushima.)

Eingegangen am 16. Juni $193 \%$.

Im Anschluss an die vorangehende Mitteilung hat Verf. weiter die Wirkung des Extraktes von Epimedium sagittatum Bak, das eine Sorte von Epimedium macranthum ist, auf isolierten Dünndarm, Uterus, Detrusor urinae, Trigonum vesicale und Hoden des Kaninchens untersucht und den Einfluss dieses Extraktes auf die Harnabsonderung des Kaninchens und auf die Geschlechtsorgane von Mäusen und Kaninchen studiert. Die Ergebnisse waren folgende: 1) Bei dem isolierten Kaninchendünndarm bewirkt der Fxtrakt in allen Dosen immer eine Hemmung, und in grossen ausschliesslich eine Lähmung. 2) Seine Wirkung kommt schon in kleineren Dosen am ausgeschnittenen Kaninchenuterus noch besser zur Geltung als an dessen Dünndarm. Er wirkt in kleinen und mittleren Dosen erregend, in grossen aber lähmend. 3) Am ausgeschnittenen Detrusor urinae des Kaninchens wirkt der Extrakt im allgemeinen in allen Dosen hemmend, besonders setzt er den Tonus deutlich herah, während er in kleineren Dosen allein sehr selten erregend wirkt. 4) Seinc Wirkung auf das Trigonum vesicale des Kanichens ist ungefähr die gleiche wie auf den Detrusor urinae. 5) Bei dem isolierten Kaninchenhoden ruft dieser Extrakt in kleineren und mittleren Dosen hauptsächlich eine hochgradige und lang andauernde Tonussteigerung hervor. Im Gegensatz dazı wirkt er aber in derselben Mengen manchmal hemmend. 6) Der Angriffspunkt des Extraktes auf diese glattmuskelige Organe ist hauptsächlich im Muskel selbst zu suchen, während das vegetative Nervensystem nicht in Mitleidenschaft gezogen wird. 7) Der Extrakt bewirkt immer eine Abnahme der Harnabsonderung des Kaninchens. Diese Wirkung nimmt mit der Gabengrösse zu. 8) Eine mehrmalige Injektion dieses Extraktes übt auf die (Geschlechtsorgane junger Mäuse sowie junger und auch erwachsener Kanin(hen keinen merklichen Winfluss aus. [Vgl. Original (Japanisch) S. 44.]

(Autoreferat.) 